\title{
大量死を伴う異常アコヤガイの血球像の変化
}

\author{
前野幸男 ${ }^{1,4 *} \cdot$ 伊東尚史 ${ }^{2} \cdot$ 釜石 隆 $^{1} \cdot$ 森実庸男 $^{3} \cdot$ 中島員洋 $^{2}$
}

(2001年 4 月23日受付)

\section{Morphological Changes of Hemocytes in Hemolymph Smear Preparations of Diseased Japanese Pearl Oyster Pinctada fucata martensii with Mass Mortality}

\author{
Yukio Maeno ${ }^{1,4 *}$, Takafumi Ito ${ }^{2}$, Takashi Kamaishi ${ }^{1}$, Tsuneo Morizane ${ }^{3}$ \\ and Kazuhiro Nakajima ${ }^{2}$ \\ ${ }^{1}$ National Research Institute of Aquaculture, Fisheries Research Agency, Nansei, Mie 516-0193, Japan \\ ${ }^{2}$ National Research Institute of Aquaculture, Fisheries Research Agency, Tamaki, Mie 519-0423, Japan \\ ${ }^{3}$ Ehime Prefectural Fisheries Station, Uwajima, Ehime 798-0087, Japan \\ ${ }^{4}$ Present address: Japan International Research Center for Agricultural \\ Sciences, Ohwashi 1-1, Tsukuba, Ibaraki 305-8686, Japan
}

(Received April 23, 2001)

\begin{abstract}
In diseased Japanese pearl oyster Pinctada fucata martensii collected from Ehime, Japan from April to July 1998 where mass mortalities of cultured pearl oyster had occurred since 1996, histopathological features such as atrophy of the connective tissue in the mantle and adductor muscle were commonly observed. These histopathological changes were also reproduced in experimental pearl oyster by inoculation with hemolymph of diseased pearl oyster. Morphological changes of hemocytes in naturally and experimentally infected Japanese pearl oyster were examined. In naturally infected oyster, enlarged cells and the presence of granules and vacuoles in the cytoplasm of hemocytes were observed in hemolymph smear preparations stained with May Grunwald-Giemsa, and these changes were consistent with the histopathological changes. In experimentally infected oyster, these morphological changes of hemocytes were also correlated with the progression of histopathological changes. These results suggest that the observation of morphological changes of hemocytes in hemolymph smear preparations can be a rapid and convenient method for presumptive diagnosis of the disease occurring in Japanese pearl oyster.
\end{abstract}

Key words: hemocyte, Pinctada fucata martensii, mass mortality, hemolymph, pearl oyster

1996年頃から西日本各地の真珠養殖場で，真珠母貝お よび挿核貝などのアコヤガイ Pinctada fucata martensii の大量死が発生し，産業上甚大な被害をもたらしている。 大量死するアコヤガイは, 閉殼筋および軟体部が赤褐色

1 独立行政法人水産総合研究センター養殖研究所南勢庁舎

2 独立行政法人水産総合研究センター養殖研究所玉城分室

3 愛媛県水産試験場

4 現所属: 独立行政法人国際農林水産業研究センター水産部

* Corresponding author

E-mail: ymaeno@jircas.affrc.go.jp
を呈する外観的特徴を有し, 異常のみられた貝は急激に やせて衰弱し死に到るものである。このアコヤガイの大 量死の原因として，これまでに水温㧍よび潮流など環境 要因の悪化・餌料生物の減少・有害プランクトンの発 生*1, 生理障害 ${ }^{* 2}$ ならびに原虫 ${ }^{* 3}$ またはウイルス感染症

*1 全国真珠養殖漁業協同組合連合会 : 平成 9 年度海面盖殖業高 度化推進対策事業 真珠盖殖業全国推進検討会報告書, 一貝 柱の赤変と組織損傷を特徴とするアコヤガイの大量へい死に 関する検討一 1998, pp. 1-113.

*2 平野瑞樹, 杉下佳之, 馬場 靖, 金井欣也, 吉越一馬：養殖 
(Suzuki et al., 1998; Miyazaki et al., 1999）などの要因が 検討されてきた（室賀ら, 1999）。

黒川ら（1999）は, 赤変異常貝の外套膜片を健常貝に 移植することにより, 外套膜において外套血管内皮細胞 の損傷, エオシンに好染する繊維成分の多い結合組織, 遊走細胞の浸潤が, 閉款筋において結合組織の増生, 筋 繊維の萎縮, 遊走細胞の浸潤が再現されることを報告し ている。また異常貝血リンパを健常貝に接種することに よっても病変が再現されている*4。これらの事実は, ア コヤガイの赤変化を伴う大量死が感染症であること, な らびに病貝の血リンパが本症病態と密接に関連すること を強く示唆するものである。

黒川ら（1999）は，赤変異常の自然発症貝および実験 感染貝を組織学的に精査した結果, 外套膜および閉款筋 の組織病変が本疾病の診断指標となることを明らかにし た。しかしながら, 病理組織学的診断法はアコヤガイを 生かしたまま検査試料を採取できないこと, 検査試料作 製に時間を要すること, 一度に大量の検査試料を処理で きないこと, 手技に習熟を要することなどの欠点もある。 本症の効果的な防除法がない現状では, 発病初期におけ る適切な処置が重要となる。そのための簡便かつ迅速な 診断法の確立が急務となっている。

本研究は, 本症の病態と密接に関連すると考えられる 血リンパに注目し, 自然発症貝および実験感染貝の血リ ンパ塗抹標本を観察し, 病理組織学的診断法と比較検討 することを目的とした。

\section{材料および方法}

\section{自然発症貝}

自然発症貝として1998年 4 月16日から 7 月15日にか けて愛媛県南部海域で飼育されていたアコヤガイ母貝 を, 毎回 3 個体ずつ計 6 回採取したものを用いた。

\section{実験感染貝}

実験感染には本症に特徵的な組織病変が観察されない 健常な石川県母貝を用い, 愛媛県産の自然発症貝より得 た血リンパを接種した。すなわち，健常貝および病貝を

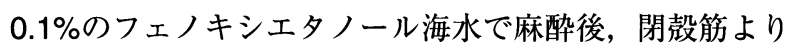
注射器で採血し血リンパを得た。病貝又は健常貝から採 取した血リンパを健常貝の閉款筋に $0.1 \mathrm{ml} /$ 個体ずつ接 種した。実験区および対照区それぞれ40個体収容し，水

アコヤガイの大量死の病理一IV. 再び消化器系の病変につい て. 平成11年度日本魚病学会春季大会講演要旨, 1998, p. 28.

*3 浜口昌巳, 鈴木伸洋, 薄 浩則, 石岡宏子：アコヤガイにお ける原虫感染症一 I. 分子生物学的検討. 平成10年度日本魚 病学会春季大会講演要旨, 1998, p. 13.

*4 森実庸男, 内村祐之, 藤田慶之, 川上秀昌, 山下浩史, 林 政博, 中島員洋, 岩本仁司, 前野幸男, 釜石 隆, 良永知義, 船越将二, 芦田勝朗: 実験感染によるアコヤガイ赤変化の再 現. 平成10年度日本魚病学会秋季大会講演要旨, 1998, p. 5.
温24.5〜 $26.5^{\circ} \mathrm{C}$ 紫外線照射海水にて77日間無給餌で飼 育した。実験区は接種 1，3，5，7，9，11週間後に，対 照区は実験開始時および実験終了時にそれぞれ 3 個体ず つ採取し, 血リンパ標本および組織標本を作製し観察に 供した。

\section{血リンパ標本および組織標本}

アコヤガイを麻酔後, 閉款筋より注射器を用いて血リ ンパ液を採取した。採取した血リンパは, スライドグラ スに滴下し, 湿箱で30分間静置し, メタノールで10分間 固定したのち, メイグリュンワルドーギムザ（メイーギ ムザ）染色を施し，血リンパ標本を作製した。血リンパ 標本は, 血球細胞数, 血球細胞の伸展の程度, 血リンパ 中の異物（あわ状構造物）の有無, 血球細胞の形態的特 徵（異常な大型細胞, 細胞質にみられる顆粒および空胞, 染色性の異常）および核の濃縮の有無について観察し た。

採血した個体の外套膜および閉款筋を Davidson の固 定液で固定後, 常法に従いパラフィンに包埋し $4 \mu \mathrm{m}$ 厚 の切片を作製した。切片はへマトキシリンーエオシン染 色を施し光学顕微鏡で観察した。

\section{外套膜および閉殻筋の病理組織像による病貝の類別}

黒川ら（1999）は，自然発症貝の病理組織像を詳細に 記載しており, 外套膜および閉款筋の組織病変が病貝に 普遍的にみられることを明らかにしている。その中で外 套膜の病変が軽度なものは閉殸筋に病変が認められにく い傾向があることから, 赤変異常貝の発生過程で初期に 生じる病理組織学的変化は外套膜においてみられるとし ている。これらに基づいて病貝の状態を Table 1 に示す ように A, B, C，およびDの 4 つに類別した。すなわち 外套膜および閉款筋のいずれにも病変のみられないもの を $\mathrm{A}$ とし, 外套膜のみに病変がみられるものを $\mathrm{B}$ とし, 外套膜および閉殸筋のいずれにも病変がみられるものを Cとした。さらに組織病変が進行し変性が重度になった ものをDとした。

\section{結果}

\section{自然発症貝}

1998年 4 月16日から同年 7 月15日にかけて採取した 自然発症貝の血リンパの性状を, Table 1 に示した病理 組織学的な分類指標に基づく組織学的判定結果ととも に, Table 2 に示した。 4 月16日の採取試料では外套膜 および閉殸筋のいずれにも組織病変はみられなかった が，5月15日の採取試料では外套膜の外套血管内皮細胞 の損傷が観察できた。6月 5 日の採取試料では外套膜の 病変に加え, 閉款筋においても筋繊維の萎縮および遊走 細胞の浸潤が観察された。6 月17日および 6 月25日の採 
Table 1. Histopathological grading of diseased pearl oysters

\begin{tabular}{lccc}
\hline & A & \multicolumn{1}{c}{ B } & D \\
\hline Mantle & Normal & $\begin{array}{l}\text { Impairment of endothelial cells of mantle arteria } \\
\text { Infiltration of hemocytes } \\
\text { Debris of dead cells in connective tissue } \\
\text { Eosinophilic fibrosis in connective tissue }\end{array}$ & $\begin{array}{l}\text { Atrophy of connective } \\
\text { tissue }\end{array}$ \\
\hline Adductor & \multicolumn{1}{c}{$\begin{array}{l}\text { Atrophy of muscle fiber } \\
\text { Infiltration of hemocytes } \\
\text { Hyperplasia of connective } \\
\text { tissue }\end{array}$} & Lysis of muscle fiber \\
\hline
\end{tabular}

Healthy and diseased pearl oysters were graded into four groups depending upon the degree of histological changes observed in the mantle and adductor.

Table 2. Histological features and hemolymph characteristics of each Japanese pearl oyster collected from Ehime Prefecture and healthy pearl oyster collected from Ishikawa Prefecture

\begin{tabular}{|c|c|c|c|c|c|c|c|c|c|c|}
\hline \multirow{2}{*}{ Date } & \multirow{2}{*}{$\begin{array}{l}\text { Histological } \\
\text { features }\end{array}$} & \multirow[b]{2}{*}{1} & \multirow[b]{2}{*}{ II } & \multirow[b]{2}{*}{ III } & \multicolumn{2}{|c|}{ Hemolymph } & \multicolumn{2}{|l|}{ features } & \multirow[b]{2}{*}{ VIII } & \multirow[b]{2}{*}{ IX } \\
\hline & & & & & IV & V & VI & VII & & \\
\hline \multirow[t]{3}{*}{16 Apr. } & A & + & + & - & - & - & - & + & + & - \\
\hline & A & + & + & - & - & - & + & - & - & + \\
\hline & A & $※$ & & & & & & & & \\
\hline \multirow[t]{3}{*}{15 May } & $B$ & + & - & + & - & + & + & + & + & + \\
\hline & A & + & + & - & - & + & - & + & + & + \\
\hline & B & ++ & + & - & - & + & - & + & + & - \\
\hline \multirow[t]{3}{*}{5 Jun. } & C & - & - & ++ & - & + & + & + & + & + \\
\hline & C & + & + & + & - & + & - & + & + & + \\
\hline & B & - & - & ++ & + & + & + & + & + & + \\
\hline \multirow[t]{3}{*}{17 Jun. } & $\mathrm{D}$ & ++ & + & - & + & + & - & + & + & - \\
\hline & D & - & - & ++ & + & + & + & + & + & + \\
\hline & C & + & - & + & + & + & + & + & + & + \\
\hline \multirow[t]{3}{*}{25 Jun. } & C & ++ & + & - & - & + & + & + & + & + \\
\hline & C & + & - & + & + & + & + & + & + & + \\
\hline & $D$ & + & - & - & - & + & + & + & + & + \\
\hline \multirow[t]{3}{*}{15 Jul. } & D & ++ & + & + & - & + & + & + & + & - \\
\hline & D & ++ & + & - & - & + & + & + & + & + \\
\hline & D & $※$ & & & & & & & & \\
\hline Healthy & A & + & ++ & - & - & - & - & - & - & + \\
\hline \multirow{2}{*}{15 Apr. } & $A$ & - & - & - & - & - & + & - & - & + \\
\hline & $A$ & + & + & - & - & - & + & - & - & + \\
\hline
\end{tabular}

Histological features: See Table 1

Hemolymph features : I, number of hemocytes; II, degree of hemocyte extension; III, bubble-like structures; IV, bacteria; V, enlarged cells; VI, hemocytes with dark-stained cytoplasm; VII, hemocytes containing granules in the cytoplasm; VIII, hemocytes with vacuoles in the cytoplasm; IX, hemocytes with pyknotic nuclei. The grade of each feature was indicated as $(++,+,-)$ for I $\sim \mathrm{III},(+,-)$ for IV IX. ※=not examined

取試料では病状がさらに進行し，外套膜では結合組織の 萎縮，閉殸筋では筋繊維の融解の重度の組織病変が認め られ，7月15日の採取試料では調査したいずれの個体も 重度の組織病変を伴う病態を示すに到った。対照として 用いた石川県産の健常貝はいずれも正常な組織像を呈し た。

血リンパ塗抹標本観察の結果, 血球細胞数の多臭およ
び血球細胞の伸展の程度は, 病貝ならびに健常貝それぞ れにおいてばらつきがみられ一定の傾向は認められな かった。あわ状構造物（Fig. 1）および細菌（Fig. 2） は, 健常貝では全くみられず, 組織病変が進行している 中等度の病貝でしばしば観察されたが, 重度の病態の個 体でも認められないものもあった。細胞質がメイーギム ザ液に濃染する（Fig. 2）血球細胞を有する個体ならび 

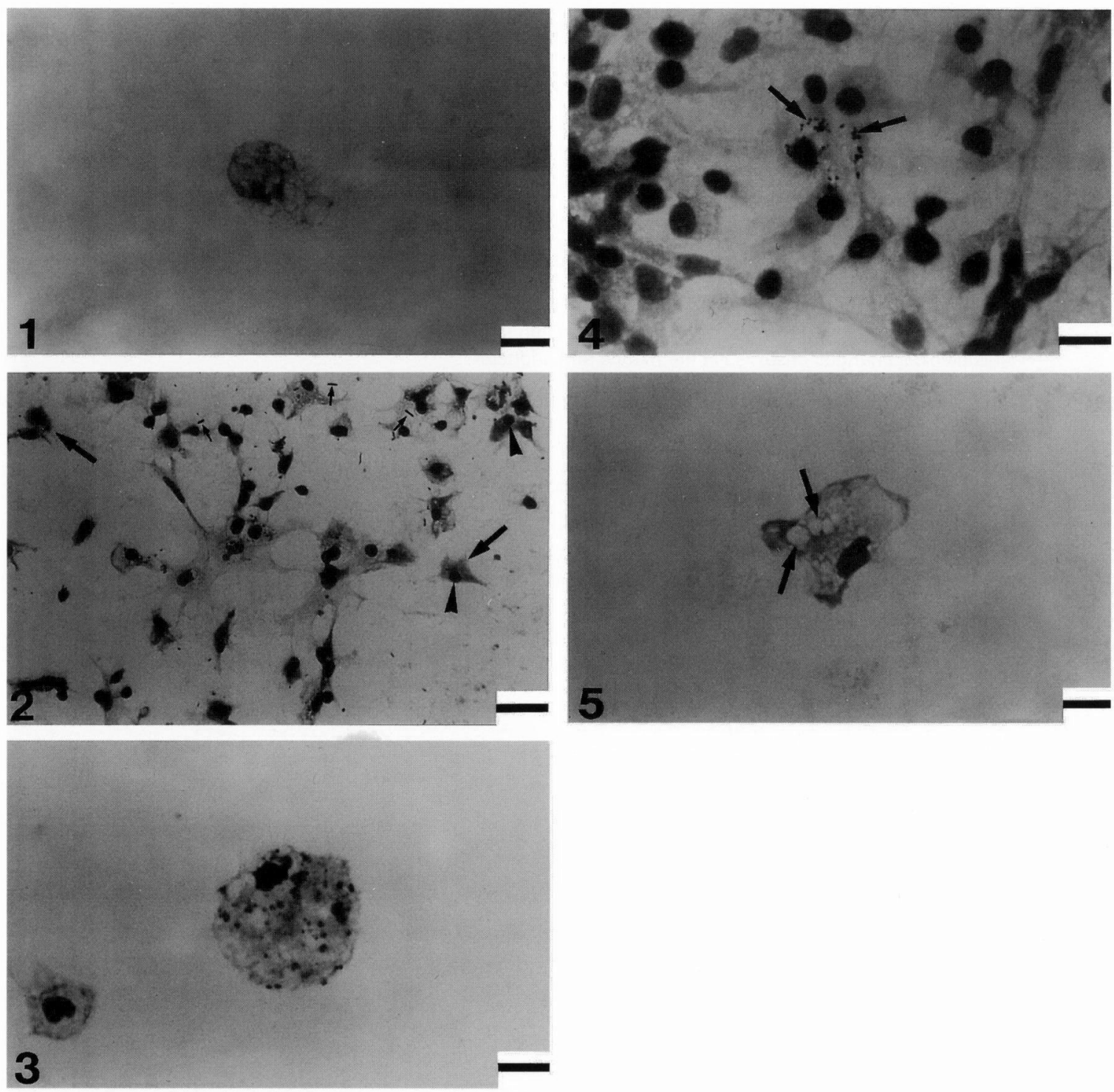

Fig. 1. Bubble like structure in a hemolymph smear preparation of a spontaneously infected pearl oyster. May-Grunwald-Giemsa staining. Scale bar $=10 \mu \mathrm{m}$

Fig. 2. A hemolymph smear preparation of a spontaneously infected pearl oyster. Note bacteria (small arrows), pyknotic nuclei (arrowheads), and dark staining in cytoplasm (big arrows) of some hemocytes. May-Grunwald-Giemsa staining. Scale bar $=20 \mu \mathrm{m}$

Fig. 3. An enlarged cell in a hemolymph smear preparation of a spontaneously infected pearl oyster. May-Grunwald-Giemsa staining. Scale bar $=10 \mu \mathrm{m}$

Fig. 4. Granules (arrows) in the cytoplasm of hemocytes in a hemolymph smear preparation of a spontaneously infected pearl oyster. May-Grunwald-Giemsa staining. Scale bar $=10 \mu \mathrm{m}$

Fig. 5. Vacuoles (arrows) in the cytoplasm of hemocytes in a hemolymph smear preparation of a spontaneously infected pearl oyster. May-Grunwald-Giemsa staining. Scale bar $=10 \mu \mathrm{m}$

に核濃縮を起こした血球細胞（Fig. 2）を有する個体は 病貝および健常貝でも観察された。これらはいずれも組 織病変の程度との相関は認められなかった。しかしなが ら異常な大型細胞 (Fig. 3)，血球細胞質にみられる顆粒 （Fig. 4）および空胞（Fig. 5）の出現は，健常貝には全 く観察されず，軽度の病態のものでもいずれも観察され， 組織病変の進行とともに出現頻度も増加するようにな り，これらは組織病変の程度とよく相関していた。

\section{実験感染貝}

実験感染貝の組織標本および血リンパ塗抹標本の経時 的な観察結果を Table 3 に示した。実験区では接種 1 週 間後から 5 週間後までは組織学的な病変は観察されな かったが, 接種 7 週間後において外套膜および閉凯筋に 組織病変が認められた。接種 9 週間後および11週間後と 時間経過につれ，それぞれ 2 個体打よび 3 個体に組織病 変が観察された。 
Table 3. Histological features and hemocyte characteristics in experimentally infected pearl oysters

\begin{tabular}{|c|c|c|c|c|}
\hline & \multirow{2}{*}{$\begin{array}{l}\text { Histological } \\
\text { feature }\end{array}$} & \multicolumn{3}{|c|}{ Hemocyte characteristics } \\
\hline & & Enlarged cells & $\begin{array}{l}\text { Hemocytes with granules } \\
\text { in the cytoplasm }\end{array}$ & $\begin{array}{l}\text { Hemocytes with vacuoles } \\
\text { in the cytoplasm }\end{array}$ \\
\hline \multicolumn{5}{|l|}{ Control } \\
\hline \multirow[t]{3}{*}{$0 * w P I$} & A & - & - & - \\
\hline & $A$ & - & - & - \\
\hline & A & - & - & - \\
\hline \multirow[t]{3}{*}{11 wPI } & $A$ & - & - & - \\
\hline & $A$ & - & - & - \\
\hline & A & - & - & - \\
\hline \multicolumn{5}{|l|}{ Infected } \\
\hline \multirow[t]{3}{*}{$1 \mathrm{wPI}$} & A & - & - & + \\
\hline & $A$ & - & + & + \\
\hline & $A$ & - & - & - \\
\hline \multirow[t]{3}{*}{$3 w P I$} & $A$ & - & - & - \\
\hline & $A$ & + & + & + \\
\hline & A & + & + & + \\
\hline \multirow[t]{3}{*}{5 wPI } & $A$ & + & + & + \\
\hline & A & + & + & + \\
\hline & A & + & + & + \\
\hline \multirow[t]{3}{*}{7 wPI } & A & - & - & - \\
\hline & $A$ & + & + & + \\
\hline & C & + & + & + \\
\hline \multirow[t]{3}{*}{$9 w P I$} & $A$ & + & + & + \\
\hline & C & + & + & + \\
\hline & C & + & + & + \\
\hline \multirow[t]{3}{*}{11 wPI } & C & + & + & + \\
\hline & C & + & + & + \\
\hline & $D$ & + & + & + \\
\hline
\end{tabular}

*WPI : weeks post-inoculation

実験感染貝において血リンパ叙抹標本観察を行ったと ころ, 血球細胞数, 血球細胞の伸展の程度, あわ状構造 物, 細菌, 血球細胞質の染色性の異常および核の小型球 形化は，いずれも組織病変との相関はみられなかった。 一方血球細胞の細胞質に顆粒や空胞が観察される個体が 接種 1 週間後にみられた。接種 3 週間後， 5 週間後およ び 7 週間後では, 異常な大型細胞および細胞質に顆粒や 空胞が観察される血球細胞を有する個体も出現した。さ らに接種 9 週間後から11週間後では, 調査したいずれの 個体にも異常な大型細胞, 細胞質に顆粒および空胞が観 察された。

対照区では実験開始時および終了時のいずれにおいて も組織病変および血球細胞の変化が観察される個体は全 くみられなかった。

\section{考察}

自然発症貝の病態を外套膜および閉款筋の組織病変を もとに類別し，血リンパ叙抹像と対比させた結果，血球
細胞数の多葟, 血球細胞の伸展の程度, あわ状構造物お よび細菌の有無, 血球細胞質の染色性の異常ならびに血 球細胞核の小型球形化の各項目には組織病変との相関は みられなかった。実験感染貝においても自然発症貝と同 様, 血球細胞数の多臭, 血球細胞の伸長程度, あわ状構 造物および細菌の有無, 血球細胞質の染色性の異常なら びに血球細胞核の小型球形化は, 組織病変との相関はみ られなかったことから,これらの血リンパ像の変化は本 症の診断指標にはなり得ないと考えられた。しかしなが ら異常な大型細胞ならびに血球細胞質にみられる顆粒お よび空胞の出現は, 自然発症貝および実験感染貝のいず れの組織病変ともよく相関していた。

実験感染貝において観察された血球が変化したと考え られる異常な大型細胞ならびに血球細胞質の顆粒および 空胞は, 接種 3 週間後および 5 週間後の組織病変が現わ れるよりも早い時期に観察された。自然発症貝において も組織病変の出現する以前の貝にも観察されたことか ら, これらの事実は血リンパ塗抹標本に扔ける血球細胞 
隆・森実庸男 · 中島員洋

の変化が, 組織病変に先だって観察される可能性を示唆 するものであるが, その詳細については今後の検討を要 する。

黒川ら（1999）は，外套膜および閉殼筋の組織病変 が, アコヤガイ大量死の病貝に普遍的に観察されること を明らかにしている。本研究では，自然発症貝および実 験感染貝において組織病変の指標をもとに病態を類別し 血リンパ像と対比した。その結果，アコヤガイ血球細胞 の変化が本症病態の指標となることが明らかとなった。 血リンパ塗抹標本によるアコヤガイ大量死の診断法は, アコヤガイを生かしたまま血リンパを採取できること， 迅速に検査試料を作製できること，大量の検査試料を処 理可能なこと, 手技に習熟を要さないことなど病理組織 学的診断法に比して迅速性および簡便性にすぐれた方法 と考えられる。

\section{謝辞}

本研究は, 農林水産省行政対応特別研究「魚介類の新
興及び再興感染症の病害防除技術の開発」によって行わ れた。

\section{文献}

黑川忠英 - 鈴木 徹 - 岡内正典 - 三輪 理 - 永井清仁 - 中村弘 二・本城凡夫・中島員洋・芦田勝朗・船越将二 (1999)： 外套膜移植および同居飼育によるアコヤガイ Pinctada fucata martensii の閉殼筋の赤变化を伴う疾病の人為的感 染. 日水誌, 65, 241-251.

Miyazaki, T., K. Goto, T. Kobayashi, T. Kageyama and M. Miyata (1999): Mass mortalities associated with a virus disease in Japanese pearl oysters Pinctada fucata martensii. Dis. Aquat. Org., 37, 1-12.

室賀清邦・乾 靖夫・松里寿彦（1999）：ワークショップ「貝 類の新しい疾病」. 魚病研究, 34, 219-231.

Suzuki, S., M. Kamakura and R. Kusuda (1998): Isolation of birnavirus from Japanese pearl oyster Pinctada fucada. Fisheries Sci., 64, 342-343. 